\title{
Local government administration in Nigeria: the search for relevance
}

\section{Commonwealth Journal of Local Governance}

Issue: December 2015

http://epress.lib.uts.edu.au/ojs/index.php/cjlg

\section{Ozohu-Suleiman Abdulhamid}

Department of Public Administration

Faculty of Management Sciences

University of Abuja, Nigeria

\section{Paul Chima}

Department of Public Administration

Faculty of Management Sciences

University of Abuja, Nigeria
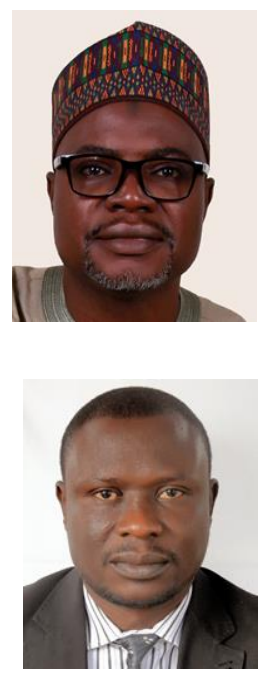

\begin{abstract}
In the general discourse on the local government system in Nigeria, two major influences are notable: the intervention of the military in politics, and the 1976 reform of local government. However, the 1979 constitution, which provided the legal framework for the 1976 reforms, plunged the local government system into a crisis of identity, and ever since local government in Nigeria has remained an idea in search of relevance. This paper examines both the inherent weakness of the constitutional foundation and the contradictions created by the 1976 reforms. Using a theoretical analysis, the paper finds that the combined effects of constitutional gaps and reform contradictions have rendered Nigeria's system of local government an unfortunate 'orphan', and that, lacking a strong constitutional foundation, local government in Nigeria has been subject to the whims of both state and federal governments. The paper argues that, despite numerous constitutional developments, current constitutional provisions for local government in Nigeria leave much to be desired. The recommendations to improve the system include that: local government should be given the status of a federating unit in the constitution, with its powers and functions clearly spelt out; the constitutionally mandated State Joint Local Government Account (SJLGA) should be abolished; and the constitution should be amended to create a chapter which guarantees the identity and autonomy of local government as a third tier of government.
\end{abstract}

Keywords: Administration, constitution, federation, government, local, reform

(C) 2015 Ozohu-Suleiman Abdulhamid and Paul Chima. This is an Open Access article distributed under the terms of the Creative Commons Attribution 4.0 Unported (CC BY 4.0) License (https://creativecommons.org/licenses/by/4.0/), allowing third parties to copy and redistribute the material in any medium or format and to remix, transform, and build upon the material for any purpose, even commercially, provided the original work is properly cited and states its license. 


\section{Introduction}

Since the 1950s, when the federal system came into operation in Nigeria, local government administration has received considerable scholarly attention (Adamolekun 1979; Gboyega 1987; Ekpo and Ndebbo 1998; Oyediran 2001; George 2010; Bamidele 2013). Gboyega, cited in Adeola (2008), observed four major epochs in the development of the local government system in Nigeria: (i) colonial rule, which was based on the traditional administrative system, and existed from 1903 until the 1950s when the native authority system became obsolete; (ii) the more liberal and participatory approach to local governance introduced in the 1950s; (iii) the advent of military rule, which replaced the model of grassroots participatory democracy with military centralisation and a 'unity of command' scheme; and (iv) the comprehensive reform of local government administration in 1976, which restored liberal participatory values.

The impact of these last two epochs on the structure and operational dynamics of local government in Nigeria is still felt. Firstly, the centralisation introduced under military rule has remained a major influence in the relationship between the federal government and local government. Secondly, the reform of local government in 1976 has continued to shape subsequent discourse and reforms. It is instructive to note that the 1976 reform acknowledged the local government system as government at local level, established by law, with defined powers. We shall return to this in due course.

Local governments are created with the ultimate goal of bringing government closer to the people at the grassroots. In Nigeria, the local government reforms aimed both to accelerate development and to enable the local population participate and hold those in power accountable for their governance roles. However, a true third tier has never taken off in the governance structure of Nigeria, despite the widespread endorsement of local government as a potent system to mobilise people for local participation in governance. Several studies have established the challenges bedevilling the Nigerian local government system, including issues such as poor funding, paucity of human capital, corruption, poor service delivery etc. However, little attention has been given to the deficiencies in the constitutional framework and the reforms that have shaped the operation of local government in Nigeria. This paper aims to review the groundswell of debate in the light of these reforms and their constitutional provisions, and assess how local government could be made more relevant.

The paper is organised into eight sections. Section one is the introduction. Section two is the problem statement; section three presents the objectives and methodology of the study; section four traces the historical evolution of Nigeria's local government system; section five explores its constitutional foundation, and section six presents key findings from the study. Sections seven and eight conclude the study and offer recommendations. 


\section{Statement of the problem}

Nigeria is undoubtedly one of the world's more prominent federal states. Like many other federal unions, the Nigerian federation has evolved over time, and has undergone considerable political restructuring to realise the object of true federalism. Perhaps unlike other federal unions, Nigeria's federalism has generated considerable debate and controversy. Part of this controversy revolves around the three-tier structure of the federation: the federal government at the centre; the Federal Capital Territory and 36 state governments; and 774 local governments.

Ever since the idea of a multi-tiered federation was conceived, there have been varying interpretations of the constitutional status of local government as the third tier of the federation. Although the 1976 reform of local government attempted to clarify this, it did not provide the legal framework to underpin any fundamental restructuring. Similarly, the 1979 constitution and the current 1999 constitution failed to provide the necessary constitutional backing to operationalise the change. This lacuna created the opportunity for manipulation by both the federal and state governments. Section 7(1) of the 1999 constitution provides that: "The system of local government by democratically elected local government councils is under this constitution guaranteed; and accordingly, the government of every state shall, subject to section 8 of this constitution, ensure their existence under a law which provides for the establishment, structure, composition, finance and functions of such councils" (authors' emphasis). The constitution assumes that the law relating to local government creation would be made by the state houses of assembly. Thus the legal framework does not see local governments as a third tier of government, but merely recognises local government as an appendage of state government where the latter enjoys absolute discretion over the former.

The constitutional status of the federal and state governments is clear and unmistakable. Thus Chapter V, Part I (Sections 47-89) of the 1999 constitution makes extensive provision for the legislative arm of government at the federal level. Similarly, Part II (sections 90-129) of the same chapter makes provisions for legislative arms of government at the state level. Provisions are also made in respect of the executive powers and functions of the federal and state governments. These provisions automatically accord the federal and state governments the constitutional autonomy and legal framework required for their operations. No such provision exists for local governments, and it is for this reason that their constitutional guarantee of third-tier status should be treated with circumspection. 
In the second schedule of the 1999 constitution, two types of legislative power are categorised, namely the Exclusive Legislative List and the Concurrent Legislative List. ${ }^{1}$ It is curious to note that in the Concurrent Legislative List no mention is made of local government - a situation that further undermines the third-tier status of LGs.

Moreover, a close perusal of the fourth schedule of the 1999 constitution, where the functions of local government are listed, reveals that local government councils are effectively administrative units of state government. For example, item 2(d) referring to the functions of local councils provides that: "The functions of a local government council in the government of a state as respects the following matters... and such other functions as may be conferred on local government councils by the House of Assembly of the state" (authors' emphasis). This provision grants state governments unfettered discretion to decide on what local governments within their state can or should do, or to usurp some of the specific local government functions set out in item 1 (a)-(k).

Finally, the attempt by the reform of 1976 to accord financial autonomy to LGs was undermined by the 1999 constitution through the introduction of the State Joint Local Government Account (SJLGA). In the 1976 reform, it was envisaged that democratic federalism would start by extending popular participation to the unit of government closest to the people, i.e. local government. This would require a workable degree of financial autonomy recognised by the constitution. However, creation of the contentious SJLGA has frustrated attempts to establish the third-tier status of local governments. The SJLGA is reviewed in detail in the discussion section of this paper.

\section{Objectives/methodology}

The main objective of this study is to review contemporary debates on the local government in Nigeria in order to underscore the relevance of the federal constitutional framework to the country's challenges. The specific objectives are to: (i) expose the constitutional fault lines that affect local government in Nigeria; (ii) identify the tendencies on the part of state actors that have contributed to this situation; and (iii) make policy recommendations that could restore and protect the status of local government administration in the spirit of true federalism.

The authors have employed both descriptive and analytical methods. This approach drew on official records, policy pronouncements and a considerable volume of related literature. In respect of official records, extant provisions of the 1979 and 1999 constitutions of the Federal Republic of Nigeria, the reports of the various national political conferences and the report of the commission on the reform of

\footnotetext{
${ }^{1}$ Exclusive Legislative List refers to items in Part I of Schedule 2 of the Constitution, referring to Federal responsibilities, and the Concurrent Legislative List is set out in Part II of the Schedule 2, referring to Federal/State responsibilities.
} 
local government in 1976 were used. A literature review provides a range of discussions on the topic. The analysis/discussion that follows draws on findings from this theoretical research.

\section{Evolution of the local government system in Nigeria}

The development of Nigeria's local government system can be traced to the Native Authority Ordinance of 1916, which was passed by the British colonial government ostensibly to leverage the existing traditional administrative systems in the different regions of the area now known as Nigeria. The ordinance was the first legal framework to operationalise a system of indirect rule (Ikeanyibe 2009). However, this attempt to unify the system of local government met informed resistance from the East and West regions, both because of its anti-democratic thrust and because the system did not fit well with the existing traditional administrative systems in those regions. Nonetheless, the ordinance endured until 1946, when the Richard constitution introduced the new regional assemblies. By 1949, the Eastern house of assembly provided a platform for debates that eventually led to the Local Government Ordinance of 1950, which set the scene for a democratic system of local government (Ogunna 1996).

By 1954, democratic values had permeated the local government system in the three regions of East, West and Northern Nigeria, with each region having absolute control over the type, structure and functions of local government (Ikeanyibe 2009). However, although the 1950 ordinance started to introduce democratic values in local governance, it also marked the beginning of federal/regional dominance over local government administration, which was evident throughout colonial rule and has endured through the post-colonial era to contemporary Nigeria.

Despite this colonial history, Nigeria's modern local government system started with the reform of local government in 1976. This reform aimed to restructure and modernise local government administration, and to make it one of the best in Africa. The good intentions of the 1976 reform included the desire to extend the principle of federation by bringing government to the grassroots level, and to achieve uniformity of local government administration across the federation (Olanipekun 1988).

The reform represented a fundamental change, because for the first time a single system of local government was attained in Nigeria. The financial system was also restructured, introducing statutory allocations of revenue from the Federation Account, ${ }^{2}$ with fixed proportions of federal and each state's revenue given to local government. According to Ekpo and Ndebbio (1998), the reform also ring-fenced revenue to protect local government revenue from state encroachment. It also defined a

\footnotetext{
${ }^{2}$ Revenue for distribution from Federal to State or local governments is distributed through the Federation Account.
} 
number of potential sources of internally generated revenue for local governments, e.g. rates, including property rates, education rates and street lighting; taxes such as community, flat rate and poll tax; and fines and fees, including court fines and fees, motor park fees, forest fees, public advertisement fees, market fees, regulated premises fees, birth registrations etc. In order to make the reforms work, local government officers and local politicians were given a free hand to operate with little or no interference in their daily affairs. State ministries for local government only had responsibility to advise, assist and guide - not to control the local governments under their jurisdiction. Traditional rulers were also protected from party politics under the 1976 reforms.

Local government was reformed again in 1988, when the federal military government introduced civil service reforms. These aimed to professionalise the local government service, by creating mandatory departments (personnel, finance, supply etc) and officers (councillors, secretary, treasurer, auditorgeneral for local government). The 1988 reform also clearly defined the functions of the Local Government Service Commission, which sets guidelines for staffing and monitoring local governments. All these provisions sought to institute responsible local government in the Nigerian federation.

\section{Constitutional foundation of local government administration in Nigeria}

Local government councils did not have definitive constitutional recognition until local government was enshrined in the 1979 constitution, which provided the legal framework to implement the 1976 reforms. The primary goal was to ensure that every state government should, by law, provide for the establishment, structure, composition, finance and functions of local councils (Diejomoah and Ebo 2010). However, this means that the degree of autonomy local councils enjoy in decision-making, strength and relevance is determined by their respective state governments, and state governments have always taken advantage of the lacuna created by this constitutional framework to dictate the financial and operational structures of local governments.

The 1979 constitution did spell out the functions and responsibilities of local government. Functions fall into three categories: areas for which local governments have full responsibility, areas where local government shares responsibility with higher levels of government, and areas of responsibility that the state or federal government may from time to time assign to local authorities (Oviasuyi et al. 2010). Additionally, the constitution guaranteed democratically elected government councils all over the country: "The system of local government by democratically elected government council is under this constitution guaranteed..." (Chapter 1, Part 2, Section 7(1)). The 1979 constitution allowed for local government to receive federal allocations, and in Section 149 prescribed that states should provide funds for local governments in their areas (Bamidele 2013). 
The 1999 constitution takes almost the same position on local government as the 1979 constitution, with some modifications. In its fourth schedule, Section 7(2), the 1999 constitution sets out the functions of local government in Nigeria. In theory, therefore, local government is a unit of government with defined powers and authority, and relative autonomy. The functional areas for local government included in the constitution are: provision and maintenance of health services; agricultural and national resource development; provision and maintenance of primary, adult and vocational education; and other functions as may be conferred on it by the state house of assembly. Section 7(1) also guarantees democratically elected governments in Nigeria. On the strength of these provisions, the 1999 constitution acknowledged the powers of local government councils as articulated in the 1976 local government reform to the effect that:

These powers should give the council substantial authority over local affairs as well as the staff and institutional and financial powers to initiate and direct the provision of services and to determine and implement projects so as to complement the activities of the state and federal government. (Ibeto and Chinyeaka, no date, p. 183)

Section $162(5,6,7,8)$ also provides for the funding of local councils through the Federation Account. Paragraph 6 specifically provides that "each state shall maintain a special account to be called the State Joint Local Government Account" into which should be paid all allocations made to local government councils from the Federation Account and from the government of the state. This is, of course, a reversal of the reform introduced by the federal government in 1988 (Abutudu 2011). The 1999 constitution, as noted by Khalil and Adelabu (2011, p. 143) in Section 4 also provides that: "The government of a state shall ensure that every person who is entitled to vote or be voted for at an election to the House of Assembly shall have the right to vote or be voted for at an election to a local government council." The 1999 constitution further empowers the Revenue Mobilisation Allocation and Fiscal Commission (RMAFC) to allocate revenue to the three tiers of government. The constitutional basis for this allocation of revenue is set out in Section 160, sub-sections (2) to (8). Thus: "Any amount standing to the credit of the Federation Account shall be distributed among the federal, state and local government councils in each state, on such terms and on such manner as may be prescribed by the National Assembly of Nigeria." In addition, the 1999 constitution states that "the government of every state shall, subject to Section 8 of the constitution, ensure their existence under a law which provides for the establishment, structure, composition, finance and functions of such council" (Constitution of the Federal Republic of Nigeria 1999, p. 88).

These provisions, among others, constitute the legal framework for local government administration in Nigeria. The implications of this constitutional foundation for a well-functioning local government administration will be examined in the latter part of this paper. 


\section{Discussion}

In discussing local government administration in contemporary Nigeria, the reforms and constitutional provisions have serious implications. Local government in a multi-ethnic federation is important in that it creates a sense of belonging among the people. It is responsible for local affairs, and designed to meet specific local needs. Laski (1975) corroborated this view when he argued that "we cannot realise the full benefit of democracy unless we begin by admitting that all problems are not central problems, and that all results of problems not central in their incidence require decisions by the populace, and the persons, where and when the incidence is most deeply felt" (Laski 1975 in Tonwe 2012). As might be expected, the constitutional developments and reforms carried out in Nigeria have attempted to capture the essence of local government. However, these attempts leave much to be desired, with many gaps evident. Their implications for a well-functioning local government system will now be explored.

Article 7 of the 1999 constitution empowers state governments to enact legislation with regard to "the establishment, structure, composition and functions" of democratically elected local government councils. The fourth schedule also assigns some critical functions to local government. However, these provisions only exist on paper. In practice, state governments have taken over most local government functions in order to justify spending funds earmarked for councils in the Joint Revenue Account. For example, Ubani notes that: "Lagos state government constructed parks in various parts of the state with money deducted from the state and local government Joint Revenue Account. In Ondo state, government constructed a modern motor park in Akure, the state capital" (2012, p. 1). Actions such as these contradict the provisions of the 1999 constitution, which provides that these projects ought to have been executed by local government.

The 1999 constitution, like the 1979 constitution, gives states very wide powers to manage issues of local government organisation and structure. This provision has proved confusing and counterproductive, for example leading to prolonged disputes between the federal government and Lagos state government. The constitutional neglect suffered by local government has resulted in a power struggle between the federal and state governments over control at the local level - a situation that has seriously hindered the democratisation process at the grass roots.

Similarly, Section 106 of the 1999 constitution provides that the minimum qualification for election as chairperson or councillor in a local government shall be the post-primary school certificate. This low threshold has made a career in local politics unattractive. A poorly-educated political officeholder who is also inexperienced in the art of governance can hardly offer meaningful leadership. 
An additional problem is that states often determine the tenure of elected members of local government councils. Wilson (2013, p. 142) observes that:

On several occasions, the states of Edo, Imo, Ondo and Rivers truncated the tenure of the democratically elected councils and replaced them with members of the ruling political party in the state, as caretaker committees. In most cases, the state governments decided not to conduct elections for the [local] councils, as in the case of Anambra State which ran a caretaker system for over six years.

This practice is an assault on the principle of popular participation in grassroots democracy.

The financial autonomy of local government has also been eroded. The 1976 local government reform, which was largely incorporated in the 1979 constitution, recommended direct funding from the Federation Account, with local government receiving a defined percentage of funds in the revenue allocation formula. This provision has been breached. Oyediran (2001) found that allocations channelled through state governments were not remitted to local governments. They were instead credited to state governments, and used by state governments to reimburse themselves for expenditure made on behalf of local governments. Abutudu (2011) notes that the Babangida regime attempted to address this problem. From 1988, the federal government removed the state government from its intermediary role in the transmission of funds from the Federation Account to local government. Until 2000, allocations from the Federation Account were collected directly by local governments from the Federal Pay Offices in their respective states. However, this changed when the 1999 constitution introduced the State Joint Local Government Account (SJLGA) (Section 160, sub-sections (2) to (8)), which provides that:

the amount standing to the credit of local government councils in the Federation Account shall be allocated to the states for the benefit of their local government councils on such terms and in such manner as may be prescribed by the National Assembly; and that each state should maintain a special account, to be called the State Joint Local Government Account, into which shall be paid all allocations to local government councils of the state from the Federation Account and from the government of the state.

The aim was that federal allocations would reach local governments via their respective state governments. However, these SJLGAs have become infamous, as allocations are misappropriated. Many state governors were accused of misappropriating local government funds during the first 12 years of democratic rule, with the aid of the SJLGA. For example, in 2010, 27 local governments in Borno State threatened mass action in protest at alleged indiscriminate deductions from their monthly allocations. Each local government lost $20 \%$ of its allocations (George 2010, p. 1). George further notes that the Nasarawa state government under Alhaji Abdullahi Adamu, in collaboration with Alhaji Aliyu Bala Usman, the Commissioner for Local Governments and Chieftaincy Affairs, also:

...allegedly abused the joint account system with reckless abandon by illegally withdrawing over 5 billion in 36 months from the state local government joint account belonging to the 16 local governments in the state. An act which is contrary to section 7 
(6) (A) 162 (5), (6) (7) and (8) of the 1999 constitution and the local government laws of Nasarawa state and the joint account laws. This offence, which is contrary and punishable under section 104 of the criminal code act, landed the former governor in the EFCC net. (George 2010, p. 1).

Some members of state houses of assembly were also alleged to have been 'paid' by their respective local governments at the end of every month. Since state houses of assembly make local government laws, some state parliaments exploit this power to extract financial rewards. Akaeze (2012) recalls a similar experience in Ogun State, where Tunde Oladunjoye, a former chair of the Ijebu East local government area, accused former governor Gbenga Daniel of diverting local government funds. The case was reported thus:

In November 2009, 'the total allocation for the 20 LGs in Ogun State was N1.7 billion. But Daniel gave us N700 million, which was less than half of what was due to us.' Before then, Oladunjoye and some of his colleagues had written to Daniel 'to deduct only what is statutory from our allocation and specifically the exact amount of money due to the teaching and non-teaching staff of the Local Government Education Authority, LGEA.' According to Oladunjoye, nothing came out of that. 'For example, my bill for LGEA was about N28 million monthly, but the governor was deducting N39 million. That is N11 million in excess. With N11 million, I could build two or three community health centres every month. I was angry. Why should state government pay primary schoolteachers on our behalf? Was the federal government paying secondary school teachers on behalf of the state government?' (Akaeze 2012, p. 3).

Daniel, the former governor, was eventually charged in court with this and other offences by the Economic and Financial Crime Commission (EFCC).

The 1999 constitution is clear on the provisions of the SJLGA. The problem faced is the arbitrary use of discretion by state governors to determine what is due to local governments.

Due to the constitutional barriers imposed by the SJLGA, and the way this account is being manipulated, LGs have become ineffective. Even with the little that reaches them, post-budget control imposes further restrictions on their operations, while local government chairs also siphon off funds using all manners of strategies.

In Benue State, for example, three sub-committees were set up in 2010 by the house of assembly to probe where funds received by local governments in the state had gone. Consequently:

12 council chairmen were suspended in the state for alleged fraud. They were asked to refund a total of 150 million naira... The chairmen to go on suspension were those of Logo, Ado, Obi, Apa, Ohimini, Oturpko and Ogbadibo local government. Others were Guma, Gwer West, Ukum, Kwande and Ushongo. (George 2010, p. 2).

In a similar development, the chairs of Ibaji and Ogori Magongo local governments in Kogi State were suspended over what was described as non-performance and misappropriation of resources. 
According to the source:

the statutory allocation of 75 million naira received by the local government for December 2008 was neither used for payment of salaries nor implementation of any meaningful project. Similarly, neither was a loan of 200 million naira or the excess crude fund of 380 million naira said to have been received by the local government judiciously used. Instead, councillors were reported to have been sponsored to Jerusalem on pilgrimage, and allowances of over 1 million naira each was made available to them, despite the traveling allowance of 500,000 naira received by each of them. (George 2010, p. 2).

The consequence of the financial strangulation of local government councils is predictable: a local government administration that is ineffectual, unable to connect with citizens, or to discharge its statutory responsibilities, and a local population without responsive local representation.

Also worthy of note is the influence of the Local Government Service Commission (LGSC) which, though not established under the 1999 constitution, has nevertheless further marginalised local government. State governments use the LGSC to set local government policies, and sometimes to obstruct local government activities. It has also been claimed that incompetent staff may be sent to a particular local government to undermine the implementation of democratically determined policies (Wilson 2013). In the case of Delta State, Wilson notes:

The LGSC took over political control of the councils where the Heads of Personnel Management (HPMs) were mandated by the LGSC through the Delta State House of Assembly to run the affairs of the councils from May 2011 - November 2012, following the expiration of the tenure of the elected councils in the state in 2011 (Wilson 2013, p. 143).

Recent political turmoil has further undermined local government. In the last 20 years, three conferences have been convened to discuss the political and constitutional future of Nigeria: the 1994/95 Constitutional Conference, the 2005 National Political Reform Conference and the 2014 National Conference. Nigeria's system of local government was a key issue discussed by participants. For example, the 1994 conference expressed serious concerns over the increasing cost of local government and, while recognising it as a third tier of government in Nigeria, recommended scrapping the legislative arm of local government to save money (Constitutional Conference 1994/95). However, the merit of minimising the cost of local government level is questionable, and it is worrying that the cost of federal and state governments was not mentioned.

The 2005 National Political Reform Conference also reaffirmed the three levels of government in the constitution, but did not address the fractured constitutional arrangements which have rendered local government administration more or less unworkable. The most protracted debates on the system of local government were at the 2014 National Conference. Unlike previous conferences, this provided ample opportunity for participants to discuss a wide range of political and constitutional issues, 
encouraged by the spirit of democracy and freedom of expression made possible by 15 continuous years of democratic rule. Perhaps in an effort to resolve the issue of funding, the conference recommended scrapping the SJLGA and replacing this with a state Revenue Mobilization, Allocation and Fiscal Commission (RMAFC) with representatives from local government and a chair nominated by the state governor. However, it also recommended a two-tier government structure - federal and state - with states able to create as many local governments as they wish (National Conference 2014).

The abolition of the SJLGA would help restore the financial autonomy of LGs and thus improve their viability, the latter recommendation can be seen as the final blow to the constitutional establishment of local governments. It decides the question of local government 'paternity' in favour of states (not central government) but exacerbates the constitutional crisis of identity. Creating a two-tier, rather than a three-tier system is a fundamental political restructuring, which automatically redefines the federation and has far-reaching implications for liberal democratic values and democratic inclusiveness. Moreover, the discretion accorded to states to create local governments may be unreasonably exercised, both as to numbers and as to operational autonomy. The authors note that in the Second Republic from 1979-1983, state governors increased the number of local governments from 301 to 1,000, while the Fourth Republic which started in 1999 under the Obasanjo administration followed suit with local government numbers increasing from 774 to 2,000 (Eme 2009). Although there is an issue as to whether so many local governments can be funded and sustained, the new arrangement severely constrains the actions of local governments, as they still lack constitutional recognition. It is clear that the relevance or otherwise of local governments to democratisation is in the hands of Nigeria's state governments.

\section{Conclusion}

The debate on the desirability of local government administration in Nigeria has had considerable impetus since the return to democracy in 1999. It is often assumed that the new framework will guide state actors to make informed policy choices in the interests of democratic federalism. This paper expresses doubt as to whether this is happening, although the choice of federalism as a principle to organise the Nigerian nation is not an accident of history. Rather, it is the predictable outcome of a political evolution dating back to the colonial era.

Under colonial rule Nigeria was conceived and nurtured from the periphery, with a system of indirect rule built on the traditional ethic administrations to create the Nigerian federation. Thus, through a series of political and constitutional developments, the Nigerian federation has evolved into what is now described as a three-tier political structure with federal, state and local units of government. 
However, the local units of governance which formed the nucleus of present Nigeria have not only been undermined, but are now undergoing major constitutional assault. With the exception of the 1976 local government reforms, which attempted to restore the sanctity of local governance, political restructuring has tended to downgrade local government administration. However, despite these assaults, the principles of democratic inclusiveness and grassroots participation ensure that local government survives. LG is fundamental to the democratisation process, as it remains the most potent instrument to mobilise people for local participation and to spread democratic values. The authors therefore conclude that, given the status of Nigeria as the largest democracy in Africa and the third largest in the world, a constitutional framework that guarantees the powers and function of local government is essential to give voice to the far-flung parts of the nation.

\section{Recommendations}

In the light of issues raised, findings generated and discussed, and the conclusions drawn, the following policy recommendations are suggested:

1. In order to drive the principle of democratic federalism to its logical conclusion and to give constitutional reality to the concept of three-tier federalism, local government should be clearly and unambiguously established in the General Provisions, Chapter I, Part I, subsection 2 of the 1999 Constitution of the Federal Republic of Nigeria.

2. Following the above, a chapter on local government as an autonomous unit of the federation should be created in the constitution, analogous to Chapter V, Parts I and II for the federal and state governments respectively. The new chapter should make provisions that ensure the legislative and executive powers and functions of local government councils. These provisions would automatically override the current ambiguous provision in Section 7, which gives state governments the leeway to manipulate local governments, usurp their statutory functions and plunder their resources.

3. The controversial SJLGA should be removed from the constitution, and replaced by a new regime of fiscal federalism where local government councils would be accountable for funds directly allocated to them.

4. This new regime of fiscal federalism would evolve measures to instil fiscal discipline among local governments and encourage self-reliance through internally generated revenue. A clear and unambiguous definition of the powers and functions of local government would help local governments improve their revenue base and fund public services without over-reliance on statutory allocations from the Federation Account. 
5. The Local Government Service Commission should be strengthened and accorded constitutional recognition. Given the commission's laudable objectives, such strengthening would support the human resource and staffing development of local governments in Nigeria.

6. Finally, the minimum qualifications for eligibility to seek election as a local government chairperson should be reviewed. In the light of the complex tasks of local governance and inclusive participation, the authors recommend that in order to stand as a local councillor, candidates should have a National Diploma or above, and at least 15 years of relevant experience. This recommendation is seen as fundamental to developing local leadership skills, which will enable local politicians to achieve national relevance.

\section{References}

Abutudu, M. (2011) The challenges and opportunities for improving the local government system in Nigeria. Paper presented at the Third Biennial National Conference on Community Development in Nigeria, Grand Hotel, Asaba, November, 20-24, 2011. Available at: www.communitylifeproject.org [Accessed 4 February 2014].

Adamolekun, L. (1979) The idea of local government as a third level of government. Ibadan: Heinemann Educational Books.

Adeola, G.L. (2008) From native authority to local government in Nigeria: Implications for flexibility and dynamism in local governance. Journal of Constitutional Development, 8 (3).

Akaeze, A. (2012) How the local government are robbed of funds. Available at: http://www.newswatchngr.com/how-the-lgs-are-robbed-of-funds [Accessed 4 February 2014].

Bamidele, G. (2013) The role of local government in federal systems. Available at: https://www.newsdiaryonline.com [Accessed 7 December 2013].

Constitution of the Federal Republic of Nigeria (1979) Available at: http://www.constitutionnet.org/vl/item/constitution-federal-republic-nigeria-1979 [Accessed 5 February 2014].

Constitution of the Federal Republic of Nigeria (1999) Available at: http://www.nigerialaw.org/ConstitutionOfTheFederalRepublicOfNigeria.htm [Accessed 5 February 2014].

Constitutional Conference Nigeria (1994/1995) Available at: http://www.nairaland.com/977832/abachasnational-constitutional-conference-1994-95 [Accessed 5 February 2014].

Diejomaoh, I. and Eboh, E. (2010) Local governments in Nigeria: Relevance and effectiveness in poverty reduction and economic development. Journal of Economics and Sustainable Development, 1 (1), 12-28.

Ekpo, A.H. and Ndebbio, J.E.U. (1998) Local government fiscal operations in Nigeria. AERC Research Paper 73, Nairobi Kenya: African Economic Research Consortium.

Eme, O.I. (2009) The fourth republic and local government creation. In: Odion-Akhaine, S. (ed) Local government administration in Nigeria: Old and New Visions. Publication of the Centre for Constitutionalism and Democratization (CENCOD). Abuja: PANAF Press.

Gboyega, A. (1987) Political values and local government in Nigeria. Lagos: Malthouse Press.

George, M. (2010) The looting of local government in Nigeria. Available at: https://newsmailonline.wordpress.com/2010/10/03/hello-world/ [Accessed 5 February 2014].

Ibeto, I. and Chinyeaka, J. (no date) Issues and challenges in local government project monitoring and evaluation in Nigeria: The way forward. European Scientific Journal, 8 (18), 180-185.

Ikeanyibe, O.M. (2009) Local government and constitutional elasticity. In: Odion-Akhaine, S (ed) Local government administration in Nigeria. Abuja: Panaf Press. 
Khalil, S. and Adelabu, S.A. (2011) Modeling local government system in Nigeria. Kuwait Chapter of Arabian Journal of Business and Management Review, 1 (1).

National Conference Nigeria. (2014) Available at: http://www.premiumtimesng.com/nationalconference/download-nigeria-2014-national-conference-report-ngconfab-2/ [Accessed 5 February 2014].

National Political Reform Conference of Nigeria. (2005) Available at: http://www.amazon.com/NationalPolitical-Conference-FEDERAL-REPUBLIC/dp/B002JUREAS [Accessed 5 February 2014].

Ogunna, A.E.C. (1996) A handbook of local government in Nigeria. Owerri: Versatile Publishers.

Olanipekun, J.M. (1988) Local government in Nigeria. Paper presented at African Leadership Forum, Ibarapa Local Government Area, Oyo State, Nigeria 27 October 1988.

Oviasuyi, P.O., Idada, W. and Isiraojie, L. (2010) Constraints of local government administration in Nigeria. Journal of Social Science, 24 (2), 81-86.

Oyediran, O. (2001) Local government as a third tier of government in Nigeria: The 1976 local government reforms and after. In: Elaigwu, J., Isawa, E. O., Uzoigwe, G.N. and Akindele, R.A. (eds) Foundations of Nigerian federalism, 1960-1995. Jos: Institute of Governance and Social Research. pp. 194-211.

Tonwe, D. (2012) Fluidity in democratic local governance: the Achilles' heel of Nigerian local government. Journal of Human and Social Sciences, 4 (2), 75-82. Available at: http://www.ajol.info/index.php/ijhss/article/viewFile/86869/76658

Ubani, J. (2012) The dead councils. Source Magazine, 32 (9), Friday July, 2012.

Wilson, G. (2013) The politics of local government reforms and democratic governance in Nigerian local governments. Journal of Developing Country Studies, 3 (1), 136-143. 